\title{
Am I an African or an American? Duboisian Double consciousness in A Raisin in the Sun
}

\author{
Tayebeh Nowrouzi (Corresponding author) \\ Department of English, Vali-Asr university of Rafsanjani, Kerman, Iran \\ E-mail: tayebehnowrouzi@gmail.com \\ Soheila Faghfori \\ Department Of English, Vali-e-Asr University of Rafsanjani, Kerman, Iran \\ E-mail: sohila_faghfori@yahoo.com
}

Received: 12-10- 2014

Accepted: 31-12- 2014

Advance Access Published: January 2015

Published: 01-05- 2015

doi:10.7575/aiac.ijalel.v.4n.3p.174 URL: http://dx.doi.org/10.7575/aiac.ijalel.v.4n.3p.174

\begin{abstract}
A Raisin in the Sun is the story that examines the problem of identity and lack of a true self consciousness among the members of an African American family. In this work, Hansberry is mainly referring to the psychological state in which African Americans are seeking whether they are Africans or Americans. In their constant search of identity, they finally comprehend that their identity is neither African nor American but African American, a merged identity. They, thus, must endeavor to reconcile the dual parts of their identity to which Dubois referred as double consciousness. Following Dubois' theory of double consciousness, this study undertakes to locate African American identity in connection to Africa and America. It, furthermore, demonstrates that their identity cannot be defined solely in regards to Africa or America even if they tried so. Their identity is a merged one, and there is no escape from it.
\end{abstract}

Keywords: Double Consciousness, Dubois, A Raisin in the Sun, Self identity

\section{Introduction}

What is the identity of Blacks in America? What is its relation to Africa and its heritage? Are they finally Americans after inhabiting more than a century in the country where they are born and grown up? These are the questions that have haunted the black populations of America since slavery. Africans were taken to America as slaves; they were prevented from their cultural practices like dancing and using drums for political policies; they encountered new cultures, religion and language. Therefore, their African heritage and identity is impaired and distorted by passage of the time. Later generations of African Americans could not gain the same cultural experience, neither the same identity as their white counterparts due to their Africanist past as well as the racial discriminations in America. They, thus, live in a situation and experience an identity and the challenges peculiar to African Americans. They, away from ancestral homeland, Africa, and born in America, a different cultural and racial context, suffer from many problems, including racism, racial discriminations in all aspects of life. These racial discriminations lead African Americans into facing up to a great psychological challenge which is the lack of a true self-consciousness. African American's identity under the influence of two different and in some cases opposing cultures are composed. They could never posses the full sense of belonging and integration into either culture; therefore, they are in constant attempt to reconcile African heritage with American upbringing. It is the case and the state that Dubois referred to as double consciousness.

The matter of African American identity is not a new considered issue but rather it has attracted the attention of many scholars since slavery. Silviano Santiago, Homi Bhabha, Bell Hooks, Paul Gilroy, all refereed to the in between position and hybridism of African American identity from diverse perspective. However, Dubois touching the bewildered sense of belonging and the in between position by his own experience and observing the other fellows' tangible experiences was the first who discerned and introduced the concept of double consciousness into African American literary canon.Therefore his ideas and works in the discussion of African American identity are of great importance.

At the time when young black woman playwrights were virtually unheard of, Lorraine Hansberry achieved unprecedented success in the production of $A$ Raisin in the Sun, winner of the New York Drama Critics Award Circle. She was the youngest American, the fifth woman, and the first African American to win the prestigious award. This rewarding honor made her the center of attention of many critics and scholars from disparities of perspective in African American literature.

Orozimbo Paolucci Neto in his essay "Masculinity and Diasporic Place of the African American Man in A Raisin in the Sun", published in 2011, elaborated on the diasporic identity in particular the development of masculinity, a part of African American identity according to the discussion of Bell hook on African American masculinity . He explained that as a result of being taken away from their culture and homeland to be enslaved in the America, especially in the 
United States, African descendants' identity, the African Americans', continues to be in transit, occupying an inbetween position in relation to Africa. He used the play A Raisin in the Sun, by Lorraine Hansberry, as an evidence of this hybrid, in-between construction of African American masculine identity, which is only reached when it combines elements from the colonizer and the African ancestors. Nevertheless, the state of double consciousness and the search for their identity in the characters of this price winning play, who are the nearest examples and representative of African Americans as many critics maintained, has not been considered. Therefore, this study aims to highlight the connections of African Americans to Africa and America in the price wining play A Raisin in the Sun by Lorraine Hansberry. It, furthermore, explores how African Americans' characters' identity is constructed under the influence of the dual countries, America and Africa to which they are connected. The study will familiarize African Americans how to live on with the double consciousness to suffer less and enjoy more of their life. Furthermore, this study can be considered as a means to inform Blacks who they really are and what position they have in America.

\title{
2. Double Consciousness
}

Dubois first described Blacks' experience of double consciousness in a seminal essay published in 1897 " Strivings of the Negro People", an Atlantic monthly article that later Dubois gave a new title-"Of Our Spiritual Strivings" to transform it into chapter 1 of The Souls of Black Folk. Initially, in the essay, he asked the question "What does it feel like to be black?" and "How does it feel to be a problem?" The problem of Negros was their exclusion from the group life of American society because they were born with a "veil" that separated them from the white world. Dubois' answer to the mentioned question was that being a Negro means experiencing a false and alienated consciousness, a double consciousness (Gooding -Williams, 2009, p. 71). Dubois (2007) presented the concept of double consciousness in the following quotation:

\begin{abstract}
After the Egyptian and Indian, the Greek and Roman, the Mongolian, the Negro is a sort of seventh son, born with a veil, and gifted with second-sight in this American world-a world which yields him no true self consciousness, but only lets him see himself through the revelation of the other world. It is a peculiar sensation, this double-consciousness, this sense of always looking at one's self through the eyes of others, of measuring one's soul by the tape of a world that looks on in amused contempt and pity. One ever feels his twoness, - an American, a Negro; two souls, two thoughts, two unreconciled strivings; two warring ideals in one dark body, whose dogged strength alone keeps it from being torn asunder. (p.364)
\end{abstract}

Many critics commented on the concept of double consciousness and its meaning from different perspectives. Some critics believed that Dubois constitutes the concept of double consciousness to define black identity and refute the common belief that Blacks were racially inferior to whites and prove that the black cultures or consciousness were not acquired completely through their contact with whites.

Dubois believed that whites have shut Blacks out from their world by placing them behind a "vast veil". They did not consider and treat them as human; they only understood Blacks in terms of race. They considered them as inferior. Thus, they imposed a negative image and definition of their race on them, and it created a psychological problem for Blacks that were not permitted "true self-consciousness". He dubbed this condition "double-consciousness" (Moor, 2008, p. 474). Robert Gooding-Williams (2009) commented that Dubois' double consciousness is the feeling of seeing oneself from the perspective of the other, or white world, where that perspective is under the influence of racial opinions: "false self consciousness that obtains among African Americans when they observe and judge themselves from the perspective of a white, Jim Crow American world that betrays the ideal of reciprocal recognition due to a contemptuous, falsifying prejudice that inaccurately represents Negro life" ( p. 80).

Furthermore, Dubois stated that African Americans for a long time strive to have a truer self:

The history of the American Negro is the history of this strife, this longing to attain self-conscious manhood, to merge his double self into a better and truer self. In this merging he wishes neither of the older selves to be lost. He would not Africanize America, for America has too much to teach the world and Africa. He would not bleach his Negro soul in a flood of white Americanism, for he knows that Negro blood has a message for the world. He simply wishes to make it possible for a man to be both a Negro and an American, without being cursed and spit upon by his fellows, without having the doors of Opportunity closed roughly in his face. (p. 9)

Dubois suggested that the aim of this striving is a self that would be truer in its conscious representation of itself. In essence, it is a striving to nullify the false self-consciousness which is double consciousness. He assumed that gaining a truer self consciousness and success in struggle for recognition would not come into being unless the destruction of white prejudice against Blacks which misrepresent Negros' life and sentence them to alienations in the white world would be brought. Then, whites would be persuaded to view Blacks as "co-workers" of culture, and it is the time that double self is merged into a truer self-consciousness and no longer Negro two-ness are conflictual for judgments, and strivings based on Negro ideals cease to conflict with the Negro's judgments and strivings based on American ideals (Gooding-Williams, 2009, p. 83-86).

\section{Double Consciousness in $A$ Raisin in the Sun}

In 1903 W.E.B. Dubois in The Souls of Black Folk articulated what he thought to be the nature of black consciousness. According to Dubois African Americans living side by side with the white American society, possessed "double- 
consciousness": a "twoness" of being an American, and a Negro; "two warring ideals in one dark body, whose dogged strength alone keeps it from being torn asunder" (p. 8). "By double consciousness" Dickson D. Bruce stated, "Dubois referred most importantly to an internal conflict in the African American individuals between what was 'African' and what was "American." .... for Dubois the essence of a distinctive African consciousness was its spirituality, a spirituality based on Africa that revealed itself in African Americans through their folklore, their history of patient suffering, and their faith" (as cited in Mocombe, 2009, p. 47). In fact, two distinctive oppositional personalities (African and American) within a single body (a Negro) that constitute double consciousness of black folk were the spiritual nature (African) and the materialistic commercial world (American).

Hansberry's portrayal of the Youngers in A Raisin in the Sun attests that they like all the other black men and women who have lived in the United States for five generations or more and worked as servants in white homes acquired some aspects of the majority culture. Thus, it provides them with a sort of intrinsic duality or as Dubois termed it double consciousness.

African Americans affected by two different cultures endeavor to "attain self-conscious manhood ". Thus, they should "merge his double self into a better and truer self" with the loss of neither of" the older selves" because both of them had something to teach to the world (Dubois, 2007, p. 9). It becomes problematic for African Americans as they seek to make a balance between African traditions and American experiences. This double-consciousness creates some of the apparent contradictions within Lorraine Hansberry's A Raisin in the Sun, such as the conflict that occurs between Mama's matriarchal rule (African) and Walter's patriarchal expectations (American) (Abbotson, 2005, p. 9).

Mama, who initially fits the popular stereotype of the Black Mammy, seems to be the head of household. She rules everyone's life, even makes a down payment on a house in an all-white neighborhood without consulting her son. All of this behavior is representative of her Africanist identity. Also the way Hansberry introduced mama to the stage reveals the African side of her identity even if she is not aware of it. "She is a woman in her early sixties, full-bodied and strong. ... She is, in a word, a beautiful woman. Her bearing is perhaps most like the noble bearing of the women of the Hereros of Southwest Africa-rather as if she imagines that as she walks she still bears a basket or a vessel upon her head "(p. 28).

However, as she begins to comprehend the destructive effect of her actions on Walter, she abandons her authority and gives him the rest of the money to invest as he wishes. In fact, mama's abandonment of matriarchy and acceptance of patriarchy represents that along with her African layer of identity, the America also plays a role in constructing her identity.

Mama in contrast to Walter emotionally survives due to the fact that she makes a balance between African and American cultures. Mamas' spirituality is so strong that can easily be visible. "She has, we can see, wit and faith of a kind that keeps her eyes lit and full of interest and expectancy. She is in a word, a beautiful woman" (p. 28). Her spirituality, as Dickson D. Bruce stated is revealed through her faith, Christianity and the history of her ancestral patient suffering. Religion is an integral part of her life. It is apparent when Mama is furious at Walter for losing the insurance money and is at a moment of great need, she asksGod for strength." MAMA Oh, God ... (She looks up to Him) Look down here-and show me the strength"(p. 83). Also, she refers to the suffering she had experienced in the racist American society and her effort to overcome it: "we was worried about not being lynched and getting to the North if we could and how to stay alive and still have a pinch of dignity too" (p. 49). Members of Mama's generation have worked hard so that their children may have a better life, a life without segregation. However, mama is a character who is also partly American with America dreams and aspirations. She tells Ruth that all the dreams she has had are buying a house in which her family can live peacefully and she can have a little garden too (p. 32). Her desire of the possession of a good house with a garden in a white neighborhood for happiness of her family is based on American ideals. It is a commonly post-World War II American materialistic belief, that ownership and possessions can provide happiness. Mama is also radical in attempting to attain this dream (Bloom, 2009, p. 39). Apparently, mama, as the member of the American society, constructs his identity under its influence.

Furthermore, in Scene three, the note on the present of gardening tools describes Mrs. Younger as "our own Mrs. Miniver ..." (p.79). Identifying mama with Mrs. Miniver who is a white English middle-class housewife, shows that they associate themselves to the white cultures. But the gift of Travis which is an oversized gardening hat worn, as he says, by [white rich] ladies "who always have it on when they work in their gardens"(p. 79) makes her instead of looking like a white "lady" in her garden, more like a slave who is about to pick cotton, which makes everyone laugh." BENEATHA (Giggling fiercely) Travis - we were trying to make Mama Mrs. Miniver—not Scarlett O’Hara!"(p. 79) All of them even mama probably know better than the others how ridiculous she looks wearing the hat. The hat and the gardening tools, associated with white cultures and presumably representative of American culture, will not make her completely American because she possesses also an African part that makes that hat on her head seem ridiculous. While mama with gardening tools seems like Mrs. Miniver, she with hat seems funny and looks like Scarlett O'Hara . In fact, naming her Scarlett O'Hara implicitly portrays mama's ancestral heritage and slavery which is the part of her African identity.

The intrusion of American cultural values is also evident in the character of Walter. The patriarchy and materialism are two values that are adopted by African Americans and Walter from mainstream white society. Walter accepting American values considers his manhood as being the head of the family and one who controls the money. However, as it is recurrently shown throughout all the women's statements during the play "the insurance money belongs to Mama" and Mama seems as she will not "give it to you [Walter] to invest in any liquor store". It is mama who decides how to 
spend the money and she is the one who exercises power in the home. In the scene that Beneath denies the existence of god, mama slaps her and forces her to repeat after her: "Now-you say after me, in my mother's house there is still God" (p. 39). And mama states "There are some ideas we ain't going to have in this house. Not long as I am at the head of this family," in contrast to Walters's patriarchy expectations, he is not given the authority to rule the home and to decide about how to spend the money. Thus, he is frustrated because he represses his heritage and attains too much of the American culture. He has forgotten that he is an African American whose identity is composed of both African and American culture. He ignores that African tradition defined manhood as striking for freedom and maintaining racial pride and dignity. Mama, Lena, ends up giving him the money, and he loses the whole money. She let him be the head of the family when he is the one that must choose how to answer Mr. lindner's offer. While Walter decides to accept the bribery money from a community leader who wants him and his family out of their neighborhood by offering them a reasonable amount of money to fulfill his racist purpose, mama reminds Walter of the traditional African values of manhood and their determinations in keeping their pride and rights: "Son - I come from five generations of people who was slaves and sharecroppers - but ain't nobody in my family never let nobody pay 'em no money that was a way of telling us we wasn't fit to walk the earth. We ain't never been that poor. [Raising her eyes and looking at him.] We ain't never been that dead inside" (p. 91). In Walter's perspective, accepting that money will bring his manhood back, as he refers to it by saying to mama that he will feel "Fine! ... Going to feel fine ... a man ..."(p. 91) if he accepts the money. But once more it is emphasized through mama and Beneatha that denying their pride for gaining money does not classify him as manly but rather unmanly. MAMA said " You won't have nothing left then, Walter Lee" (p. 91). And his sister even mentions that by behaving in such a way he "is not a man. That is nothing but a toothless rat" (p. 91). At last, Walter acts like a "real" man and makes the right decision and tells the community leader, Mr. Lindner that they have decided to move into their house because his father has earned it for them brick by brick. He adds they don't want to make trouble for anyone and they have no reason to fight for. He emphasizes that they will do their best to be good neighbors (p. 94). And it is then that mama says" He finally come into his manhood today, didn't he? Kind of like a rainbow after the rain"(p. 95). Walter by understanding African traditional values and sewing it together with white American beliefs is able to create his own identity and gain his manhood (Paolucci Neto, 2011).

The other American value that tempted Blacks to follow it is materialism. Dubois related materialism to the white culture and urged the Negroes not to assume money as the whole meaning of life: "Atlanta must not lead the South to dream of material prosperity as the touchstone of all success; already the fatal might of this idea is beginning to spread" (p. 56).

Walter, as Dubois described, is obsessed with materialism and considers it as the meaning of life. His materialistic desire is stimulated by white communities; he tells his mother that the coming future is nothing for him. Because he is not prosperous, he perceives no prospect for himself. In despair, he compares himself with white guys whom he has seen in cool, quiet-looking restaurants where they are sitting back, talking, and turning deals worth millions of dollars. Mama asks him why he thinks so much about money and if money is so important for him; he replies that money is life. In contrast to his mother and African American ancestors, freedom has no meaning for him. It is only money that brings meaning to his life (49).

He considers wealth as the solution to his frustration, the emotional tension of his marital relationship as well as his family problems. In his perspective, gaining wealth will bring happiness and meaning to his life and other members of the family. His Dreams are completely based on economic success and he reveals it to Travis. In his dream, all he thinks about are directly related to money even his and his families happiness is due to wealth. He thinks of a business transaction that is going to change their lives. He has a car, a plain black Chrysler with white walls and black tires. He dreams of getting a car, a little sportier for Ruth, maybe a Cadillac that will be convertible for doing her shopping.

In his dreams he is a wealthy man that has no problem with Ruth and they are living in peace. In reality, they are always arguing with each other even for unimportant things. But in his dreams, Ruth comes downstairs and welcomes Walter with a kiss when he comes home from work. Then, they get into the house arm in arm. In dreams, Walter seems a happy new person. The difference in reality and dreams derives from the absence and presence of the affluence. Out of the dream, he is not wealthy so he is frustrated and irate at his poor conditions. Therefore, his frustration affects his behavior towards his family especially Ruth, and it prevents him from behaving friendly as in his dreams. In the dream, his desire of money is fulfilled so that there remains no reason for frustrations. Then, he is capable of treating his family as he wishes. He thinks in a wrong way that if he gets wealthy, consequently, the racism will be abolished. He thinks then everything will be ok; they will be accepted in white community; there remains no reason for racism; racism will not afflict his son; he can be educated and go to every school he will desire. In fact, obsession of materialism makes him daydream and forget the real nature of racism that cannot be solved solely by material positions.

With putting too much emphasis on materialism, he is ignoring and sacrificing the African part of his identity which is the spirituality and pride. He has forgotten how his ancestors fought against racism to keep their rights and pride. But at the end, we see how he balances between African and American values and regained his dignity, and revolutionary spirit. Refusing Mr. Lindner's offer does not mean that he gives up his American identity and values completely; rather it implies that he made a balance between them. At the end of the play, his recommendation to Beneatha for her marriage reveals that he has kept the American value of materialism.

"WALTER Girl, if you don't get all them silly ideas out your head! You better marry yourself a man with some loot ...

BENEATHA (Angrily, precisely as in the first scene of the play) What have you got to do with who I marry! 
WALTER Plenty. Now I think George Murchison-

BENEATHA George Murchison! I wouldn't marry him if he was Adam and I was Eve!"(p. 95)

He believes that money is important in choosing a spouse, and he suggests his sister to take it into account.

Beneatha is the other character affected by Walter's American values and his patriarchal and chauvinistic ideas. Walter overvalues himself and his dreams and plans so he expects mama to give money to him not Beneatha. He believes that as a male member of the family he is the one that deserves to gain the money. Thus, he lashes out at Beneatha to demean her dream and it reveals his chauvinism: "Who the hell told you had to be a doctor? If you so crazy about messing round with sick people - then go be a nurse like other women — or just get married and be quiet." Amiri Baraka affirmed Walter chauvinistic behavior: "On one level Walter Lee is merely aspiring to full and acknowledged humanity; on another level he yearns to strut his 'manhood,' a predictable mix of machismo and fantasy" (as cited in Bloom,2009, p. 85).

In addition to Americana, africanism is evident in the play. For instance, it is evident in the scene that he drunkenly assumes the stance of an African chieftain. He said "In my heart of hearts - (He thumps his chest) - I am much warrior! " He unconsciously possess that proud and revolutionary spirit which is his heritage and in his drunken state, it reveals itself. When he at the end refuses to accept the offer of Mr. Lindner, he becomes the symbolic father of the aggressive, and black revolutionary spirit (Wilkerson, 1983, p. 11). While Walter jumps on the table, and pretends to hold a spear, he yells, "THE LION IS WAKING," he refers to the African countries that were beginning to demand their independence from colonial rule during this period. In this episode, the inner Walter is speaking so, implicitly, he refers to his African identity and revolutionary spirit that he has oppressed through his emphasis on American materialism. His revolutionary spirit and pride is waking like a lion and will not let his materialism defeat it.

The other character that possesses double consciousness is Beneatha. She is looking for her identity as she says to Mr. Asagai that she is looking for her identity; she wants to talk with him about Africa; she is in search of her identity in Africa (p.42). The point is that she sometimes forgets that she is an African American not an African and not an American alone. Her identity is the merging of Africanism and Americanism and none of them should be sacrificed. Beneatha's searching for her true identity represents that she is in hesitations and doubt. She does not know if she is an African or American. Beneatha is in the cross roads that Dubois explained in "The Conservation of Races":

what, after all, am I? Am I an American or am I a Negro? Can I be both? Or is it my duty to cease to be a Negro as soon as possible and be an American? If I strive as a Negro, am I not perpetuating the very cleft that threatens and separates black and white America? Is not my only possible practical aim the subduction of all that is Negro in me to the American? Does my black blood place upon me any more obligation to assert my nationality than German, or Irish, or Italian blood would. (p.184)

In her hesitations of being an African or American, she looks more to Africa and Negro blood and says that she wants to be "the queen of the Nile". In fact, she misses the influence of America. In the scene that Beneatha tries on African robes that Asagai has bought her, Hansberry described her 'emerging grandly from the doorway so that we can see her thoroughly robed in the costume Asagai bought $[\ldots]$ she is coquettishly fanning herself with an ornate oriental fan, mistakenly more like a butterfly than any Nigerian that ever lived"(p. 51). While Beneatha may seek to affirm her African identity untouched by the American culture, Hansberry emphasized on the incongruity of her African sighs in America. The robe does not suit to Beneatha because she is not an African but an African American.

Hansberry portrayed Beneatha's mixed identity in distinct ways several times despite of her unawareness of it. When George meets Beneatha to go out, Beneatha removes her headdress to reveal the hairstyle that Asagai had encouraged her to wear, "close-cropped and unstraightened," George is shocked. George believes that Beneatha in Nigerian costume and natural hairstyle looks eccentric. These natural hair and costume reveals Beneatha's attempted connection to Africa. But she gets too African that is not proper for an African American girl. Before they leave for their date, George changes his mind when he sees Beneatha dressed in a cocktail dress, deciding that the hair is stylish: "I like it. It's sharp. I mean it really is." To him, when she is wearing a Western dress, the hair looks stylish, but when she is dressed in the African robes, the hair makes her look too "African" (Bloom, 2009, p. 36) . Beneatha who merges cocktail dress, which represents American culture with natural hair style which presents African culture seems pleasant because it is her true identity.

She is against assimilation and " assimilationist Negroes", who she defines as "someone who is willing to give up his own culture and submerge himself completely in the dominant, and in this case oppressive culture"(p.54). While she herself defines assimilations as being completely under the influence of American culture, she mistakenly considers the blues as a form of assimilations. "She promenades to the radio and, with an arrogant flourish, turns off the good loud blues that is playing.) Beneatha says, "Enough of this assimilations junk!"(p. 51) In fact, it refers to her unawareness of her mixed identity. Hansberry utilized the blues to refer to the merged consciousness of African Americans. The Youngers listen to it almost constantly and it reveals their merged consciousness. The blues is a culturally merged aesthetic form, a blend of African descendent, and rural Southern black sound transported to the urban North to give voice to urban problems. Beneatha's rejection of the blues implies her hesitations and inability in comprehending her true identity. 
Dubois responded to the African American identity hesitation; he noted that Negroes are Americans by birth, citizenship, their political ideals, their language, and their religion. Their Americanism does not go further, and they are Negroes, members of a vast historic race. Beneatha needs to find her own identity, which lies somewhere between the Americanness of George and the Africanness of Asagai. Mistakenly, she is looking for her identity in African heritage alone. Her belief that her identity is rooted in her ancestry and her enthusiasm to know more about Africa implies the African part of her identity while it does not refute the role America plays in her identity. Medovoi endorses this point in his brief discussion of the play in Rebels, writing: "Beneatha looks to Asagai and to Africa for her identity because it is the "African" part of her African Americaness that keeps her "younger," allowing her to cling to her idealism and to resist capitulation to the suburban regime of American whiteness" (p. 320). Although Beneatha desires to identify with African cultures and to live outside the dominant white culture she enjoys, and experiences middle-class luxuries and extracurricular activities which are often considered "white" pursuits including acting lessons, horseback riding, and playing guitar. It all proves the duality of her consciousness that partly is African and partly American. Furthermore, when Mama and Beneatha are discussing her future professional plans, Mama tells Beneatha that with the help of God, she will be a doctor but she disagrees and attributes her success to her own efforts. She believes that her success has nothing to do with God. Mama gets shocked but Beneatha continues firmly to express her atheistic ideas. She counters with mama's beliefs; she denies the existence of God; she is disgusted of hearing about God and associating mankinds' achievements to themselves. She believes that human beings can make the impossible possible and miracles happen by their efforts and hard working. God is only an idea that she does not accept ( p. 35). Beneatha's atheism is not homegrown and not based on African tradition but rather it initiates as a result of her education and the influence of American culture (Bloom, 2009, p. 156). Beneatha cannot resist her American part of her identity despite of her efforts. In the last scene, when Asagai proposes Beneatha and invites her to Nigeria: "Nigeria. Home. I will . . teach you the old songs and ways of our people - and, in time, we will pretend that you have only been away for a day" (p. 87). Beneatha needs time to think for Asagai's proposal. Her hesitation suggests that she might not be very eager to go to Africa, Nigeria, after all. In spite of her strong longing for African values, Beneatha, like many African- Americans, believes her real home is America after all. Africa is historically and culturally invaluable, but America also has many things to offer to her ( Bloom , 2009, p. 107) . Beneatha will not find her identity in Africa, because she is also American though she is right to suggest that African Americans need a better understanding of Africa as a part of their heritage. Beneatha and Walter's pride in their African roots is important, but they also need to have pride in their American-born. Her hesitation, at last reveals that her consciousness is connected to America, too (Abbotson, 2005, p. 9).

Moreover, the language of Beneatha reveals her double consciousness. According to Lois Tyson " double consciousness sometimes involves speaking two languages" (p. 362). Beneatha sometimes uses statements and expressions that are common in Ebonics, black vernacular English, for instance "that raggedly-looking old things" while in some other occasions, particularly in speaking with her white friends or assimilated Negroes, she utilizes Standard English. She uses the complex tense verbs and the words that should be explained to the other members of the family." I have never asked anyone here to do something for me"(p. 27) "I hate assimilationist Negroes.... It means someone who is willing to give up his own culture and submerge himself completely in the dominant and in this case oppressive culture!"(p. 54)

\section{Conclusions}

Africans taken forcibly to America did not leave their culture and heritage behind but rather they carry it with themselves in the new land, America. Although with passage of the time, this culture has been distorted and transformed by the effort of white masters, the presence of its essence can be traced in the descendants of the enslaved Blacks. The remained African heritage and culture played a significant role in the formation of African American identity that cannot be overlooked. The mainstreams white culture to which they have been in constant contact also were influential in African American identity. Thus, their identity is not and cannot be purely African or American but rather a merged one. This is the state that Dubois referred to as double consciousness, two souls, two thought, two different ideals in a dark body.

This experience of lack of a true self consciousness is common among all African Americans on different scale and form. Hansberry, in A Raisin in the Sun, addressed black duality and double consciousness and endeavored to investigate its aftermaths in the White-dominated society where most of the African American families are trying to find their place and truer identity, and overcome the oppressions that they are confronted with. She represented that Youngers family living in America acquired some aspects of the majority culture along with some preserving aspects of African cultures. They are the products of merging cultures and values and should make a balance between them. Mama's matriarchy and her spirituality are her African values that she preserves while her dream of possession of a house with a garden rests on American values of the time. She is not frustrated and disappointed as Walter because she is able to make a balance between the dual parts of her identity and get nearer to her true identity. On the other hand, Walter, at the beginning of the play ignores African part of his identity and is obsessed with materialism and patriarchy of American culture that he is ready to sacrifice his African pride, dignity and rights that his ancestors inherited him. Thus, he is frustrated with no true self. But at the end, when he regards his pride and dignity worthy and violates against racism of Mr. Lindner, in fact he recovers the African part of his identity. Refusing Mr. Lindner's offer does not mean that he gives up his American identity and values completely, but rather it implied that he makes a balance between them. At the end of the play, His recommendations to Beneatha for her marriage "You better marry yourself a man with some loot ..."(p. 95) revealed that he has kept the American value of materialism. 
Beneatha is one of the other characters with a double consciousness that is bewildered in the American society. She is hesitating if she is African or American. In contrast to Walter, she is too impressed with her African heritage that cannot comprehend the necessity and the role of American cultures in her identity. She is educated and she replaces the idea that she has learnt at home with the ideas she has learnt at the college. She enjoys doing the works that are mainly related to white Americans. All these revealed her American aspects of her identity that she ignores. Her hesitation to accept going with Assegai to Africa, home, implies that she is going to accept that she is African American not solely African.

\section{References}

Abbotson, S. S W. (2005). Thematic guide to modern drama. Westport : Greenwood

Blake, M . (2012). Meanings And Typologies Of Double Consciousness Within 20Th Century United States Racial Dynamics. Diss. U of Massachusetts Boston.

Bloom, H. (2009). Bloom's guides: Lorraine Hansberry's A Raisin in the Sun. New York: Infobase Publishing.

Carter, Steven R . (1985). Images of men in Lorraine Hansberry's writing. Black American literature forum, 19( 4), 160-162.

Dubois,W. E. B.(2007) . Oxford world's classics, The Souls of Black Folks. Ed. Edwards Brent. New York: Oxford UP. Gooding-Williams, R. (2009). In Shadow of Dubois, Afro-Modern Political Thought in America. Cambridge: Harvard University Press.

Hansberry, L. (2011). A Raisin in the Sun. New York: A Division of Random House.

James, R. (1992). Cliffs Notes on A Raisin in the Sun. New York: Cliff Notes.

Matthews, K. L. (Winter 2008). The Politics of "Home" in Lorraine Hansberry's A Raisin in the Sun. Modern Drama, $51(4), 556-578$.

Mocombe, P.C. (2009). The Soul-less Souls of Black Folk, A Sociological Reconsideration of Black Consciousness as Duboisian Double Consciousness. Lanham: University Press of America.

Moore, J.H. (2008) . Encyclopedia of Race and Racism. Detroit: Thomson Gale.

Paolucci Neto , O. (2011). Masculinity and the Diasporic place of the African American Man in a Raisin in the Sun. Anais do Silel 2( 2).

Rabaka, R. (2010). Against Epistemic Apartheid, W. E. B. Dubois and the Disciplinary Decadence of Sociology. Lanham: Lexington.

Wilkerson, M. B. (1983) "The Sighted Eyes and Feeling Heart of Lorraine Hansberry." Black American Literature Forum, 17 (1), 8-13. 